\title{
INHeRItANCE OF RESistance TO PROTOPORPHYRINOGen OXIDASE INHIBITOR HERBICIDES IN WILD POINSETTIA ${ }^{1}$
}

\author{
Herança da Resistência aos Herbicidas Inibidores da Protoporfirinogênio Oxidase em Leiteiro
}

BRUSAMARELlO, A.P. ${ }^{2}$, OLIVEIRA, P.H. ${ }^{2}$, TREZZI, M.M. ${ }^{2}$, XAVIER, E. ${ }^{2}$, and DALOSTO, E.D. ${ }^{2}$

\begin{abstract}
Weed resistance to herbicides is a major global problem for agriculture. In recent years, the increased use of herbicides, without proper planning, has led to a large increase in the number of cases of weed biotypes that are resistant to one or more herbicide mechanism of action. Wild poinsettia biotypes (Euphorbia heterophylla), discovered in the State of Paraná, with resistance to herbicides that inhibit protoporphyrinogen oxidase (PROTOX) and acetolactate synthase (ALS), are the first case to exhibit multiple resistance in Brazil. This study analyzed the genetic inheritance of PROTOX inhibiting herbicide resistance in $E$. heterophylla. Crosses were conducted between biotypes that were susceptible (female parent) and those carrying multiple resistance to ALS and PROTOX inhibitors (male parent) to obtain the $F_{1}$ generation. Backcrosses were performed $\left(R_{1}\right.$ and $\left.R C_{2}\right)$ and the $F_{1}$ generation was advanced to $\mathrm{F}_{2} . \mathrm{F}_{1}, \mathrm{~F}_{2}, \mathrm{RC}_{1}, \mathrm{RC}_{2}$ generation plants and their parents were subjected to applications of the herbicide fomesafen ( $250 \mathrm{~g}$ i.a. ha ${ }^{-1}$ ). The observed frequencies in the $\mathrm{F}_{2}$ generation were not different from the expected frequency of $3: 1$. All $\mathrm{RC}_{2}$ individuals were resistant, while the $\mathrm{RC}_{1}$ population showed a 1:1 segregation, which would be expected when a single gene controls the trait. Thus, it can be inferred that $E$. heterophylla resistance to PROTOX-inhibiting herbicides is conditioned by a single and dominant nuclear gene.
\end{abstract}

Keywords: Euphorbia heterophylla, hybridization, genetics, herbicide.

\begin{abstract}
RESUMO - A resistência de plantas daninhas a herbicidas é um dos maiores problemas na agricultura em todo o mundo. Nos últimos anos, a intensificação do uso de herbicidas sem planejamento adequado levou a grande aumento do número de casos de biótipos de plantas daninhas resistentes a mais de um mecanismo de ação herbicida. Biótipos de leiteiro (Euphorbia heterophylla) com resistência aos herbicidas inibidores das enzimas protoporfirinogênio oxidase (PROTOX) e acetolactato sintase (ALS), descobertos no Estado do Paraná, constituem o primeiro caso de resistência múltipla detectado no Brasil. O presente trabalho objetivou estudar a herança genética da resistência de $\boldsymbol{E}$. heterophylla a herbicidas inibidores da PROTOX. Foram realizados cruzamentos entre biótipo suscetivel (genitor feminino) e aquele com resistência múltipla aos inibidores da ALS e PROTOX (genitor masculino) para obtenção da geração $F_{1}$. Em seguida, foram realizados retrocruzamentos $\left(R C_{1}\right.$ e $\left.R C_{2}\right)$, e a geração $F_{1}$ foi avançada para $F_{2}$. Plantas das gerações $F_{1}, F_{2}, R C_{1}$ e $R C_{2}$ e os genitores foram submetidos à aplicação do herbicida fomesafen $\left(250 \mathrm{~g}\right.$ i.a. $\left.h a^{-1}\right)$. As frequências observadas na geração $F_{2}$ não diferiram da frequência esperada de 3:1. Todos os indivíduos do $\mathrm{RC}_{2}$ foram resistentes, enquanto a população do $R C_{1}$ apresentou segregação de 1:1, resultados esperados quando o caractere é governado por um único gene. Com isso, pode-se inferir que a resistência de $\mathbf{E}$. heterophylla aos herbicidas inibidores da PROTOX é condicionada por um único gene dominante e nuclear.
\end{abstract}

Palavras-chave: Euphorbia heterophylla, hibridação, genética, herbicida.

Recebido para publicação em 5.11.2015 e aprovado em 17.2.2016.

Universidade Tecnológica Federal do Paraná, Pato Branco-PR, Brasil, <antoniopedro1991@hotmail.com>. 


\section{INTRODUCTION}

Wild poinsettia (Euphorbia heterophylla) native to tropical and subtropical regions of the Americas (Kissmann and Groth, 1992) and very abundant in cultivated areas in the South, Central West and Southeast regions of Brazil (Vargas et al., 1999), is one of the most feared weed species in these areas. Among the biological characteristics that hinder the control of wild poinsettia in crops include its rapid initial development, emergence in flows and the high genetic variability of the species (Trezzi et al., 2014). This weed species shows rapid multiplication, has a high growth rate and is highly competitive with cultivated species (Kissmann and Groth, 1992). Its reproduction can occur either through selffertilization or cross-fertilization (Barroso, 2002).

The protoporphyrinogen oxidase (PROTOX) inhibiting herbicides are widely used to control annual broadleaf weeds (Merotto Jr. and Vidal, 2001; Osipe et al., 2011). However, high selection pressure, due to the misuse of herbicides with this mechanism of action, has led to the emergence of resistant weed populations (Heap, 2015).

Currently, there are seven weed species globally with resistance to this mechanism of action; the first case was a biotype of waterhemp (Amaranthus tuberculatus $(=A$. rudis $)$ ) detected in the State of Kansas (USA), in 2001 (Heap, 2015). In 2004, a biotype of $E$. heterophylla with multiple resistance to PROTOX and ALS inhibiting herbicides was recorded in the State of Paraná (Brazil) (Trezzi et al., 2005). In 2005, resistance was identified in a biotype of Ambrosia artemisiifolia in the State of Delaware (USA) and Amaranthus hybridus (syn: quitensis), in Bolivia. In 2011, resistance to this mechanism of action was observed in Descurainia sophia and Acalypha australis, in China, and the most recent record of resistance was in a biotype of Senecio vernalis in Israel, in 2014 (Heap, 2015).

Resistance to PROTOX inhibiting herbicides observed in E. heterophylla biotypes is of great concern, as this species is present in many countries worldwide an can be found in number of different crops. The resistance is a complex and difficult problem to solve, since it reduces the number of herbicides that can be used as alternative controls and can lead to economic losses and have a high environmental impact.

In suspected areas, confirming or not the existence of resistant populations is carried out through dose response curves (Gazziero et al., 2009). After confirming resistance, other aspects often neglected by research should be investigated, such as the use of alternative methods of control and prevention, the mechanism responsible for the resistance, the genetic inheritance of resistance, the number of genes involved and the comparative adaptability between resistant and susceptible biotypes.

Biotypes of Euphorbia heterophylla carrying multiple resistance were investigated for various aspects of the resistance mechanism, such as metabolism, detoxifying enzyme activity, site of absorption and site of action (Trezzi et al., 2009a,b; 2011, 2013). For these biotypes, the ALS inhibitor resistance mechanism indicates a change in the site of action of the ALS enzyme (Xavier et al., 2013), but to date there are no conclusive results for the mechanism of resistance to PROTOX inhibitors.

The mechanism of resistance to PROTOX inhibitors was first elucidated in biotypes of $A$. tuberculatus, wherein a change in the amino acid sequence of the PROTOX enzyme determined the resistance, and a single nuclear gene with incomplete dominance was responsible for the mutation of the enzyme (Lee et al., 2008; Patzoldt et al., 2006). The discovery of the mechanism of resistance to PROTOX inhibiting herbicides in Ambrosia artemisiifolia biotypes biotypes is the second case of resistance elucidated, in which a mutation in the PROTOX enzyme, with through the substitution of an arginine for a leucine at position 98 confers resistance conditioned by a single nuclear gene with incomplete dominance (Rousonelos et al., 2012).

The evolution of resistance in weeds is a classic example of rapid adaptation to face the selection pressure. Management strategies that aim to slow or prevent resistance should be supported through the understanding of 
evolutionary and ecological factors driving the selection of resistant populations (Neve et al., 2014). Knowledge of genetic inheritance helps in the understanding of the emergence and evolution of resistance, which allows the selection of management techniques that are intended to prevent or delay its onset (Christoffoleti et al., 1994).

Given the above, the present study analyzed the genetic inheritance, the number of genes and the genetic effects involved in E. heterophylla resistance to PROTOX inhibiting herbicides.

\section{MATERIAL AND METHODS}

Seeds of the susceptible and resistant biotypes used in this study came from the bulk collection of seed from 20 E. heterophylla plants randomly assigned to soybean crop areas located in the State of Paraná. The biotype susceptible (S) came from the municipality of Renascença (PR), while the biotype resistant to ALS and PROTOX enzyme inhibitors (R) came from the municipality of Vitorino (PR). Plants were sown in pots containing $5 \mathrm{~kg}$ of soil. Throughout the experiment, the temperature in the greenhouse was maintained between $23^{\circ} \mathrm{C}$ and $28^{\circ} \mathrm{C}$. The $\mathrm{S}$ and $\mathrm{R}$ biotypes were subjected to repeated self-fertilization and the selection of $\mathrm{S}$ and $\mathrm{R}$ plants was achieved through the application of ALS and PROTOX inhibiting herbicides (Trezzi et al., 2005).

For crosses, we used the biotype $\mathrm{S}$ as a female parent and the biotype $\mathrm{R}$ as a male parent. Prior to crossing, the inflorescences were isolated to prevent unwanted pollination and to facilitate the collection of seeds. Emasculation and pollination were performed between stages 2-4 of flower development, during which there is a better probability of fertilization and formation of 3 seeds per cyathium (Vargas et al., 1999). Pollination was started on the same day as emasculation and continued on subsequent days until fertilization was confirmed by observing the curvature of the pedicel (Vargas et al., 1999).

$\mathrm{F}_{1}$ generation plants were backcrossed with their susceptible $\left(\mathrm{RC}_{1}\right)$ and resistant $\left(\mathrm{RC}_{2}\right)$ parents. Along with backcrosses, the $F_{1}$ generation was subjected to self-fertilization to obtain a segregating $\mathrm{F}_{2}$.
$\mathrm{F}_{1}, \mathrm{~F}_{2}, \mathrm{RC}_{1}, \mathrm{RC}_{2}$ generations and parents were sown in 128 cell trays containing substrate. When the plants were at the stage of having two true leaves, they were subjected to the application of $250 \mathrm{~g} \mathrm{ha}^{-1}$ fomesafen. The reaction to the herbicide was assessed 7 days after application (DAA). For herbicide application, we used a $\mathrm{CO}_{2}$ pressurized backpack sprayer with a spray bar with three nozzles spaced $0.5 \mathrm{~m}$ apart and with a spray volume of $200 \mathrm{~L} \mathrm{ha}^{-1}$.

Phenotyping was performed for each plant through the analysis of the level of control provided by the herbicide, using the scale for control and injury evaluation proposed by Frans et al. (1986). An individual was considered resistant when the level of control was between $0-40 \%$ and was considered susceptible when control was between 60-100\%.

Gene effects and broad and narrow heritability were obtained by means of the components of variance, calculated from the variances $\left(\sigma^{2}\right)$ of generations $\mathrm{S}, \mathrm{R}, \mathrm{F}_{1}, \mathrm{~F}_{2}, \mathrm{RC}_{1}$ and $\mathrm{RC}_{2}$, using the formulas proposed by Ramalho et al. (2008), with the aid of the software Libre Office Calc (Libre Office, 2013). The number of genes involved in resistance was determined from the analysis of phenotypic frequency distributions, and the models for one or more genes were tested by Chi-square test using the software Genes (Cruz, 2013).

\section{RESULTS AND DISCUSSION}

There was a high phenotypic variance, a relatively low influence of the environment and a high effect of additivity, indicating the significant contribution of additivity for the expression of resistance (Table 1). The high variance observed in $F_{2}$ promoted a high variance of additivity, so that the dominance variance was underestimated and restricted heritability was overestimated.

The high broad sense heritability at $97.86 \%$ indicates that the genotype greatly participates in the expression of PROTOX inhibitor resistance (Table 1). Thus, the resistant plant descendants will always express this trait.

Plants of the $F_{1}$ generation proved to be completely resistant, showing that the male parent passed this trait of resistance to its 
descendants (Table 2). Thus, the gene determining the resistance to PROTOX inhibiting herbicides in E. heterophylla is dominant and has nuclear inheritance, that is, it can be transmitted to descendants via pollen or seed (Tranel and Wright, 2002) through the father or mother, given the lack of maternal effect.

In the $\mathrm{F}_{2}$ generation, the segregation found for the number of genes involved in resistance was 2.84:1.16 (R:S), which, according to the chi-square test, was not different from the ratio of $3: 1$ (R:S), expected for inheritance with a single nuclear gene with complete dominance (Table 2). It is evident, therefore, that the resistance to PROTOX inhibiting herbicides in E. heterophylla is due to a single nuclear gene with complete dominance.

The susceptible backcross $\left(\mathrm{RC}_{1}\right)$ showed a segregation of 1.09:0.91 (R:S) and was not different, according to the chi-squared test, from the segregation of $1: 1$, expected for traits controlled by a single gene. In the resistant backcross $\left(\mathrm{RC}_{2}\right)$, all plants were resistant, also showing the dominance of resistance (Table 2).

Results similar to those obtained with E. heterophylla were observed for Amaranthus tuberculatus (Patzoldt et al., 2006) and Ambrosia artemissiifolia (Rousonelos et al., 2012) resistant to PROTOX inhibiting herbicides, wherein the resistance is conditioned by a single dominant nuclear gene, but with incomplete dominance.

In E. heterophylla, inheritance of PROTOX inhibitors resistance is nuclear, which is important, since genetic traits with this type of inheritance, in species that exhibit crossfertilization, are rapidly disseminated through the population by pollen flow (Mariani et al., 2015; Powles and Yu, 2010).

Reproduction in E. heterophylla can occur either by self-fertilization or cross-fertilization. Furthermore, wild poinsettia plants show dispersal by explosive dehiscence, which favors gene flow by seeds. Some insects have relative influence on gene flow in E. heterophylla, as they are attracted by the large amount of nectar produced and are capable of carrying pollen and, therefore, promoting cross-fertilization (Doll, 1996), and transmitting resistance to susceptible plants.

Gene flow through plant pollen depends on specific and environmental characteristics and has a leptokurtic behavior (most dispersal found close to the donor plant), but

Table 1 - Estimates of environmental $(V e)$, additive $(V a)$, dominance $(V d)$, genetic $(V g)$, phenotypic ( $V f)$ variance components and the heritability in the broad $\left(h^{2}\right)$ and restricted $\left(h^{2}\right)$ senses for E. heterophylla resistant to PROTOX inhibitors. UTFPR, Pato Branco-PR, 2013

\begin{tabular}{|c|c|c|c|c|c|c|}
\hline \multicolumn{5}{|c|}{ Variance component } & \multicolumn{2}{c|}{ Heritability } \\
\hline$V e$ & $V a$ & $V d$ & $V g$ & $V f$ & $h^{2}{ }_{a}$ & $h_{r}{ }_{r}$ \\
\hline 16.72 & 846.28 & -81.73 & 764.55 & 781.27 & 97.86 & 108.32 \\
\hline
\end{tabular}

Table 2 - Evaluation of segregation of crosses and backcrosses between susceptible and resistant biotypes of E. heterophylla. UTFPR, Pato Branco-PR, 2013

\begin{tabular}{|c|c|c|c|c|c|c|c|c|}
\hline Population & $\begin{array}{c}\text { Total } \\
\text { plants }\end{array}$ & Resistant & Susceptible & $\begin{array}{c}\text { Expected } \\
\text { ratio }\end{array}$ & $\begin{array}{c}\text { Observed } \\
\text { ratio }\end{array}$ & $\chi_{\text {Cal }}^{2}$ & $\chi_{\text {Tab }}^{2}$ & $\sigma^{2}$ \\
\hline $\mathrm{S}$ & 100 & 0 & 100 & - & - & - & - & 19.91 \\
\hline $\mathrm{R}$ & 86 & 86 & 0 & - & - & - & - & 10.25 \\
\hline $\mathrm{F}_{1}$ & 5 & 5 & 0 & $1: 0$ & $1: 0$ & 0.00 & - & 20.00 \\
\hline $\mathrm{F}_{2}$ & 131 & 93 & 38 & $3: 1$ & $2.84: 1.16$ & 1.12 & 3.84 & 781.27 \\
\hline $\mathrm{RC}_{1}$ & 79 & 43 & 36 & $1: 1$ & $1.09: 0.91$ & 0.62 & 3.84 & 707.17 \\
\hline $\mathrm{RC}_{2}$ & 44 & 44 & 0 & $1: 0$ & $1: 0$ & 0.00 & - & 9.09 \\
\hline
\end{tabular}

$\chi^{2}$ value indicates the probability of differences between observed and expected frequencies are due to chance. 
the effectiveness of dispersal increases when there is contribution by pollinating insects (Diggle and Neve, 2001), such as in E. heterophylla.

For some species, stress situations determine the highest rates of cross fertilization with increased pollen flow, while the absence of stress situations result in an increased rate of self-fertilization (Radosevich et al., 2007). Nevertheless, there are no data in the literature determining if E. heterophylla exhibits this plastic behavior, or quantifying the maximum distance of pollen flow.

The development of further studies using molecular markers will enable the identification of genetic markers associated with the resistance, allowing the genotyping of segregating populations, genetic mapping, and when combined with sequencing, it will enable the location of the gene and the mutation that confers the resistance.

The results of this study support the conclusion that resistance of Euphorbia heterophylla to PROTOX inhibiting herbicides is controlled by a single gene, the gene action involved has complete dominance and the genic effects observed are of an additive nature.

\section{REFERENCES}

Barroso G.M. Sistemática de angiospermas do Brasil. $2^{\mathrm{a}}$.ed. Viçosa, MG: UFV, 2002. 377p.

Christoffoleti P.J.; Victoria Filho R., Silva, C.B. Resistência de plantas daninhas aos herbicidas. Planta Daninha.

$1994 ; 12 ; 13-20$.

Cruz C.D. GENES - a software package for analysis in experimental statistics and quantitative genetics. Acta Sci Agron. 2013;35:271-6.

Diggle A.J., Neve P. The population dynamics and genetics of herbicide resistance - a modeling approach. In: Powles S., Shaner D.L., editors. Herbicide resistance and world grains. Boca Raton: CRC Press, 2001. p.61-99.

Doll J. Malezas de hoja ancha-Euphorbia heterophylla L. In: LABRADA, R.; CASELEY, J.C.; PARKER, C. Manejo de malezas para países en desarrollo. (Estudio FAO Producción y Protección Vegetal, 120). [Accessed in: 7 Sep. 2015] Available at:http://www.fao.org/docrep/t1147s/ t1147s09.htm\#euphorbia heterophylla 1 .
Frans R. et al. Experimental design and techniques for measuring and plant responses to weed control practices. In: Camper N.D. Research methods in weed science. $3^{\text {rd }}$. ed. Champaign: Southern Weed Science Society, 1986. p.29-46.

Gazziero D. et al. Critérios para relatos oficiais estatísticos de biótipos de plantas daninhas resistentes a herbicidas. In:

Agostinetto D., Vargas L., organizadores. Resistência de plantas daninhas a herbicidas no Brasil. Passo Fundo: Berthier, 2009. 350p.

Heap I. The international survey of herbicide resistant weeds. [Accessed on: 20 Ago. 2015] Available in: http:// weedscience.org/

Kissmann K.G., Groth, D. Plantas infestantes e nocivas. São Paulo: BASF, 1992. 648p.

Lee R.M., Hager A.G., Tranel, P.J. Prevalence of a novel resistance mechanism to PPO-Inhibiting herbicides in waterhemp (Amaranthus tuberculatus). Weed Sci. 2008;56:371-5.

Libre Office. Versão 4.0.3.3. [Accessed on: 15 Mar. 2015]. Available at: http://www.libreoffice.org/

Mariani F. et al. Herança da resistência de Lolium multiflorum ao Iodosulfuron-Methyl Sodium. Planta Daninha. 2015;33:351-6.

Merotto Jr A., Vidal R.A. Herbicidas inibidores da PROTOX. In: Vidal R., Merotto Jr A. Herbicidologia. Porto Alegre: Evangraf, 2001. 152p.

Neve P. et al. Expanding the eco-evolutionary context of herbicide resistance research. Pest Manage Sci. 2014;70:1385-96.

Osipe J.B. et al. Sistemas de manejo de plantas daninhas na pré-semeadura da soja. Rev Bras Herbic. 2011;10:64-73.

Patzoldt W.L. et al. A codon deletion confers resistance to herbicides inhibiting protoporphyrinogen oxidase. Proc Nat Acad Sci USA. 2006;103:12329-34.

Powles S.B., Yu Q. Evolution in action: plants resistant to herbicides. Ann Rev Plant Biol. 2010;61:317-47.

Radosevich S.R., Holt J.S., Ghersa C.M. Ecology of weeds and invasive plants: relationship to agriculture and natural resource management. New Jersey: Wiley, 2007. 454p.

Ramalho M.A.P., Santos J.B., Pinto C.A.B.P. Genética na agropecuária. $4^{\mathrm{a}}$. ed. Lavras: UFLA, 2008. 464p.

Rousonelos, S.L. et al. Characterization of a Common Ragweed (Ambrosia artemisiifolia) Population Resistant to ALS- and PPO-Inhibiting Herbicides. Weed Sci. 2012;60:335-44.

Tranel P.J., Wright T.R. Resistance of weeds to ALS inhibiting herbicides: what have we learned? Weed Sci. 2002;50:700-12. 
Trezzi M.M. et al. Multiple resistance of acetolactate synthase and protoporphyrinogen oxidase inhibitors in Euphorbia heterophylla biotypes. J Environ Sci Health Part B. 2005;40:101-9.

Trezzi M.M. et al. Local de absorção de fomesafen como mecanismo de resistência em biótipo de Euphorbia heterophylla resistente aos inibidores da PROTOX. Planta Daninha. 2009a;27:139-48.

Trezzi M.M., Nunes A.L., Portes E.S. Interação entre inseticida organofosforado e herbicidas inibidores da PROTOX e sua implicação na resistência de Euphorbia heterophylla. Sci Agr. 2009b;10:423-8.
Trezzi M.M. et al. Eletrolite Leakage as a technique to diagnose Euphorbia heterophylla biotypes resistant to PPOinhibitors herbicides. Planta Daninha. 2011;29:655-62.

Trezzi M.M., Machado A.B., Xavier E. Soja: Impacto do leiteiro e estratégias de manejo. Cultivar. 2014;183:8-10.

Vargas L., Borém A., Silva A.A. Técnicas de cruzamentos controlados em Euphorbia heterophylla L. Bragantia. 1999;58:23-7.

Xavier E. et al. Acetolactate synthase activity in Euphorbia heterophylla resistant to ALS- and protox- inhibiting herbicides. Planta Daninha. 2013;31:867-74. 